\title{
Kajian Peningkatan Efisiensi Energi di Industri Pulp dan Kertas
}

\author{
Ari Kabul Paminto ${ }^{1, *}$, Rudy Surya Sitorus ${ }^{1}$, Rizki Firmansyah ${ }^{1}$, Nurus Sahari Laili ${ }^{1}$ \\ ${ }^{1}$ Pusat Pengkajian Industri Proses dan Energi (PPIPE), Badan Pengkajian dan Penerapan Teknologi
}

\author{
Naskah diterima 01/10/2019; direvisi 01/04/2020; disetujui 15/04/2020 \\ doi: https://doi.org/10.24843/JEM.2020.v13.i01.p01
}

\begin{abstract}
Abstrak
Pertumbuhan industri pulp dan kertas diproyeksi akan mengalami perkembangan yang signifikan. Menurut asosiasi industri, pertumbuhan itu antara lain karena terdorong oleh peningkatan permintaan dan produksi seiring dengan beroperasinya beberapa pabrik baru. Industri pulp dan kertas memberikan sumbangan yang cukup besar terhadap PDB (Produk Domestik Bruto) mencapai 101,76 triliun rupiah (harga berlaku). Sumber energi utama industri ini meliputi energi panas dalam bentuk steam dan energi listrik. Dari keseluruhan proses, penggunaan energi panas mencapai $70-80 \%$ dari total energi yang dikonsumsi, dimana sebagian besar energi digunakan di proses pulping dan pengeringan. Steam dapat dibangkitkan dari black liquor dan bahan bakar lainnya seperti batubara, minyak, gas dan biomassa. Kebutuhan energi industri pulp dan kertas akan meningkat rata-rata 2,49\% per tahun dari 108,5 juta SBM pada tahun 2018 menjadi 135,4 juta SBM pada tahun 2027, sehingga termasuk industri dengan konsumsi energi yang cukup besar. Sehingga perlu adanya inovasi penggunaan teknologi dengan efisiensi tinggi sehingga mengurangi penggunaan energi. Sampai saat ini lindi hitam (black liquor) dari pabrik pulp dan kertas di Indonesia pada umumnya belum dimanfaatkan secara optimal sebagai bahan bakar boiler. Upaya pemanfaatan black liquor dan penerapan teknologi yang efisien di industri pulp dan kertas mampu membantu mengurangi ketergantungan pada bahan bakar fosil serta mengurangi emisi dari bahan bakar fosil. Dengan skenario efisiensi energi, kebutuhan energi industri pulp dan kertas akan menurun sebesar $12,5 \%$ pada tahun 2027. Potensi penghematan energi industri pulp dan kertas mulai tahun 2023 sebanyak 8,4 juta SBM dan menjadi 16,9 juta SBM pada tahun 2027. Besar peluang penghematan dan reduksi emisi bervariasi dan bergantung pada berbagai faktor, antara lain tingkat efisiensi proses dan teknologi yang telah diimplementasikan di industri tersebut.
\end{abstract}

Kata kunci: Efisiensi energi, intensitas energi, black liquor, pulp dan kertas

\section{Abstract}

Growth in the pulp and paper industry is projected to experience significant development. According to industry associations, the growth was partly driven by increased demand and production in line with the operation of several new factories. The pulp and paper industry has made a significant contribution to GDP (Gross Domestic Product) reaching 101.76 trillion rupiah (current prices). The industry's main energy sources include heat energy in the form of steam and electricity. From the whole process, the use of heat energy reaches $70-80 \%$ of the total energy consumed, where most of the energy is used in the pulping and drying process. Steam can be generated from black liquor and other fuels such as coal, oil, gas and biomass. The energy needs of the pulp and paper industry will increase by an average of $2.49 \%$ per year from 108.5 million BOE in 2018 to 135.4 million BOE in 2027, making it one of the industries with considerable energy consumption. So, it is necessary to innovate the use of technology with high efficiency thereby reducing energy used. Until now, black liquor from the pulp and paper factory in Indonesia in general has not been used optimally as boiler fuel. Efforts to use black liquor and the efficient application of technology in the pulp and paper industry can help reduce dependence on fossil fuels and reduce emissions from fossil fuels. Under the energy efficiency scenario, the energy needs of the pulp and paper industry will decrease by $12.5 \%$ by 2027 . The potential energy savings of the pulp and paper industry starting in 2023 are 8.4 million SBM and to 16.9 million SBM in 2027. Large the opportunity for saving and reducing emissions varies and depends on various factors, including the level of process efficiency and technology that has been implemented in the industry.

Keywords: Energy efficiency, energy intensity, black liquor, pulp and paper

\section{Pendahuluan}

Pertumbuhan industri pulp dan kertas diproyeksi akan mengalami perkembangan yang signifikan. Menurut asosiasi industri, pertumbuhan itu antara lain karena terdorong oleh peningkatan permintaan dan peningkatan produksi seiring dengan beroperasinya beberapa pabrik baru. Industri pulp dan kertas bisa tumbuh optimal jika pemerintah serius mendorong ekspor dan mendukung industri dalam negeri. Sebab, saat ini industri pulp dan kertas dinilai kurang efisien karena masih menggunakan bahan baku pulp dan waste paper impor bersertifikat SVLK, sehingga mengakibatkan biaya produksi tinggi.

Industri pulp dan kertas memberikan sumbangan yang cukup besar terhadap penyediaan lapangan kerja serta PDB (Produk Domestik Bruto) nasional.
Pada tahun 2018 kontribusi industri pulp dan kertas terhadap PDB nasional mencapai 101,76 triliun Rupiah (harga berlaku) atau sekitar $0,69 \%$ dari total PDB nasional [1]. Nilai tambah industri pulp dan kertas tersebut sedikit mengalami peningkatan jika dibandingkan pada tahun 2017 sebesar 5,14 triliun Rupiah. Dengan pertumbuhan PDB industri pulp dan kertas maka kebutuhan energi di industri tersebut diperkirakan semakin meningkat.

Industri pulp dan kertas termasuk industri dengan konsumsi energi yang cukup besar. Kebutuhan energi sektor industri sendiri merupakan konsumen energi final terbesar kedua di Indonesia saat ini setelah sektor transportasi [2]. Industri pulp dan kertas Indonesia memiliki keunggulan komparatif bila dibandingkan dengan negara lain. Keunggulan 
tersebut diantaranya adalah dari segi bahan baku. Indonesia mempunyai potensi untuk menguasai pasar pulp dan kertas dunia karena mempunyai ketersediaan bahan baku melimpah yang berupa wilayah hutan dan pohon jenis Acacia dan Eucalyptus yang dapat tumbuh dengan periode yang cukup cepat ( \pm 5 tahun) [3].

Namun demikian dalam pengembangan ke depan perlu adanya inovasi penggunaan teknologi dengan efisiensi tinggi sehingga dapat mengurangi penggunaan energi yang sangat besar. Teknologi energi untuk industri pulp dan kertas terus dikembangkan dengan tujuan untuk meningkatkan efisiensi penggunaan energi. Disamping itu inovasi teknologi proses terus dikembangkan agar mampu menurunkan penggunaan energi dalam memproduksi pulp dan kertas.

Dalam proses produksi di industri pulp dan kertas dapat menggunakan energi baru terbarukan diantaranya pemakaian biomassa, sebagai upaya implementasi konservasi energi. Sejalan dengan itu, pemerintah mengeluarkan Peraturan Pemerintah No. 79 tahun 2014 tentang kebijakan energi nasional. Mengacu pada kebijakan tersebut, target pada tahun 2025 elastisitas energi kurang dari 1 (satu) dan intensitas energi turun 1 (satu) persen per tahun. Sehingga Pemerintah berusaha mendorong semua sektor terutama industri pulp dan kertas untuk melakukan langkah-langkah dalam upaya penghematan energi melalui penggunaan teknologi yang efisien.

Sampai saat ini lindi hitam (black liquor) dari pabrik pulp dan kertas di Indonesia pada umumnya belum dimanfaatkan secara optimal sebagai bahan bakar boiler. Dalam rangka peningkatan pemanfaatan limbah organik tersebut, pabrik pulp dan kertas diharapkan mempunyai alternatif untuk menghasilkan energi dari black liquor yang merupakan produk sampingan dari proses produksi.

Upaya pemanfaatan black liquor dan penerapan teknologi yang efisien di industri pulp dan kertas mampu membantu mengurangi ketergantungan pada bahan bakar fosil serta mengurangi emisi dari bahan bakar fosil. Penggunaan energi di setiap industri pulp dan kertas sangat ditentukan oleh jenis produk yang dihasilkan dan teknologi peralatan yang dipasang. Efisiensi energi adalah metrik kunci, baik dalam hal konsumsi energi, dampak lingkungan dan kinerja keuangan pabrik, dan perlu dipantau secara rutin dan terus-menerus untuk meningkatkan efisiensi energi [4].

\section{Metode Penelitian}

Kajian Efisiensi Energi di Industri Pulp dan Kertas ini dilakukan melalui metodologi kuantitatif dan kualitatif. Metodologi kuantitatif berdasarkan data primer (survei dan wawancara lapangan) dan data sekunder yang digunakan sebagai masukan untuk perhitungan konsumsi energi dan untuk melihat prospek efisiensi energi di masa depan. Metodologi kualitatif dilakukan melalui studi literatur untuk melihat permasalahan serta kebijakan industri pulp dan kertas saat ini. Tahapan kajian ini dibagi menjadi beberapa tahapan terlihat pada gambar 1 .

Data yang digunakan dalam kajian ini adalah data sekunder yang dikumpulkan dari lembaga pemerintah yang terkait dan publikasi beberapa industri pulp dan kertas. Data yang dikumpulkan meliputi:

- Data publikasi yang diterbitkan oleh instansiinstansi pemerintah, seperti Kementerian Perindustrian, Badan Pusat Statistik, dll;

- Publikasi yang diterbitkan oleh APP (Asia Pulp and Paper), dan APRIL Group.

- Publikasi yang dikeluarkan oleh lembagalembaga penelitian;

Data lain seperti data koefisien emisi GRK yang dikeluarkan oleh Intergovernmental Panel on Climate Change (IPCC). Saat ini IPCC Guideline yang digunakan sebagai pegangan untuk perhitungan koefisien emisi adalah IPCC Guidelines for National Greenhouse Gas Inventories tahun 2006 [5].

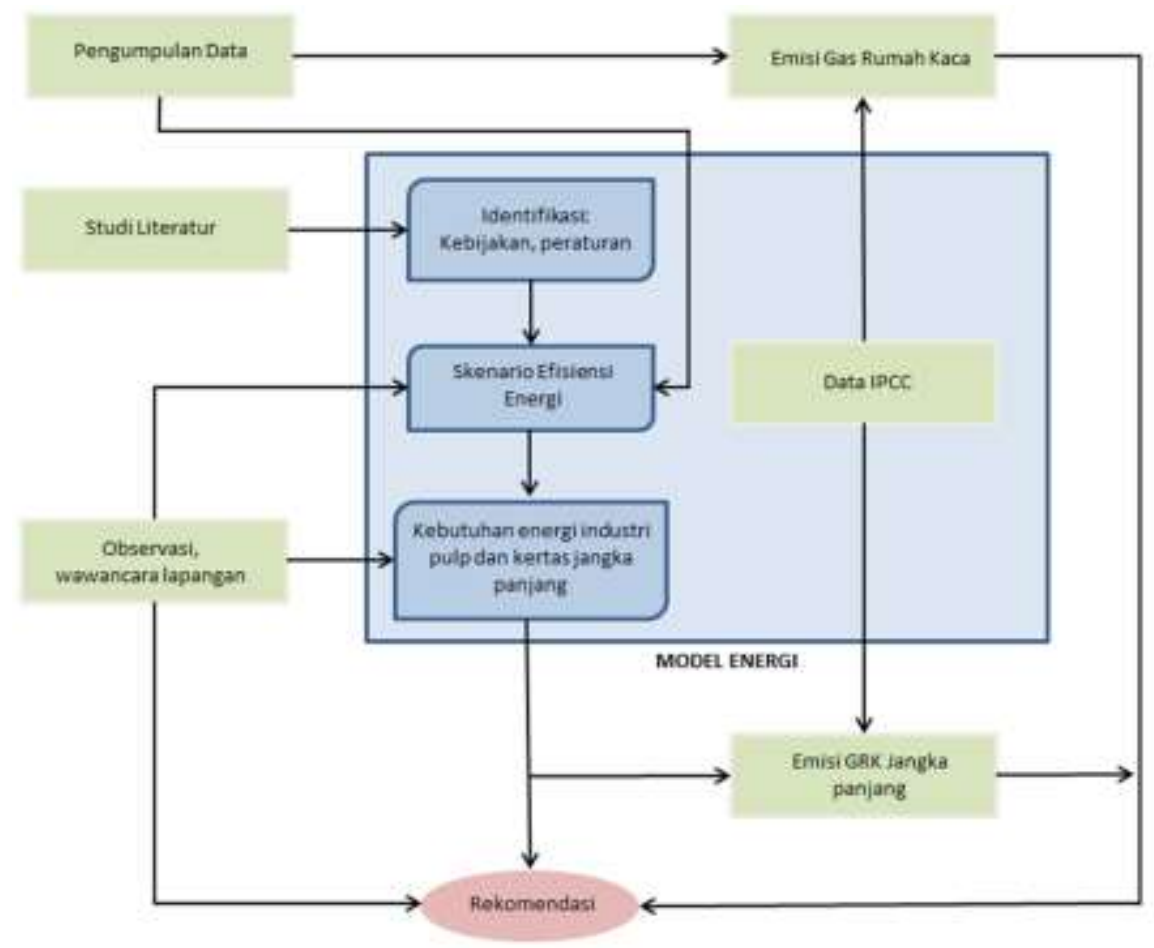

Gambar 1. Tahapan Studi Energi Industri Pulp dan Kertas 
Berdasarkan temuan-temuan kondisi yang ada saat ini dan kebijakan atau program yang telah dilaksanakan maka dapat dibuat proyeksi kebutuhan energi industri pulp dan kertas jangka panjang. Kebutuhan energi ke depan akan meningkat seiring dengan PDB atau pertumbuhan ekonomi. Berdasarkan perhitungan data historis dan proyeksi maka dapat dilakukan analisis tentang efisiensi energi industri pulp dan kertas.

Prakiraan energi dihitung berdasarkan besarnya aktivitas pemakaian energi dan besarnya pemakaian energi per aktivitas (intensitas pemakaian energi). Aktivitas energi dicerminkan oleh pertumbuhan ekonomi dan jumlah kapasitas produksi industri. Sedangkan intensitas energi merupakan tingkat konsumsi energi per produksi dalam waktu tertentu. Intensitas energi dapat dianggap tetap selama periode simulasi atau mengalami penurunan untuk menunjukkan skenario meningkatnya efisiensi pada sisi permintaan. Secara garis besar rumus matematis untuk perhitungan ditunjukkan pada rumus berikut ini:

$$
\underset{\text { Energi }}{\text { Permintaan }}=\underset{\text { Energi }}{\text { Intensitas }} \times \underset{\text { Energi }}{\stackrel{\text { Aktivitas }}{\text { Eng }}}
$$

\section{Hasil dan Pembahasan}

3.1. Progress Penggunaaan Energi Industri Pulp dan Kertas di Dunia

Sektor industri kertas dunia berbenah untuk mengurangi intensitas konsumsi energi dan emisi $\mathrm{CO}_{2}$ yan dihasilkan. Di beberapa negara maju khususnya negara yang memiliki industri kertas, berbagai upaya inovasi proses dan implementasi konservasi energi (KE) secara terus menerus telah dilakukan. Upaya program KE tersebut juga disertai dengan upaya pengembangan dan penerapan teknologi yang efisien.

Sektor pulp, kertas, dan percetakan menyumbang $5,6 \%$ dari konsumsi energi sektor industri global pada tahun 2014 [4]. Meskipun penggunaan energinya mengalami penurunan sejak tahun 2000, sektor ini terus menjadi salah satu konsumen energi industri teratas, dan dapat memainkan peran penting dalam transisi ke sistem energi rendah karbon. Meskipun terdapat pertumbuhan produksi, penggunaan energi sektor ini harus menurun sebesar $0,8 \%$ dan emisi $\mathrm{CO}_{2}$ non-biomassa sebesar $17 \%$ pada tahun 2025 dari level 2014 untuk memenuhi 2DS [4].

Penggunaan energi sektor ini telah tumbuh hanya $1 \%$ sejak tahun 2000, meskipun ada peningkatan produksi kertas dan kertas sebesar $23 \%$. Pemulihan dan daur ulang kertas limbah terus meningkat. Pemanfaatan kertas daur ulang tumbuh menjadi $55,3 \%$ pada tahun 2014 , naik dari $44,3 \%$ pada tahun 2000 dan 33,9\% pada tahun 1990. Tren ini diperkirakan akan terus berlanjut, tumbuh menjadi $57,6 \%$ pada 2DS pada tahun 2025.

Di Eropa, industri pulp dan kertas diwakili oleh Confederation of European Paper Industries (CEPI), yang saat ini mengumpulkan 18 asosiasi eropa. Pada 2016, CEPI mewakili 92\% industri pulp dan kertas Eropa dalam hal produksi. Total produksi yang dilaporkan pada tahun 2016 oleh 18 asosiasi CEPI adalah 37,2 juta ton pulp dan sekitar 91 juta ton kertas dan karton [6]. Berdasarkan statistik CEPI, pada 2015,
$24,5 \%$ dari produksi global pulp dan $26,1 \%$ dari produksi kertas dan papan global dibuat oleh perusahaan-perusahaan Eropa. Secara keseluruhan, UE adalah net importir untuk bubur kertas dan net eksportir produk kertas, kertas daur ulang serta produk papan.

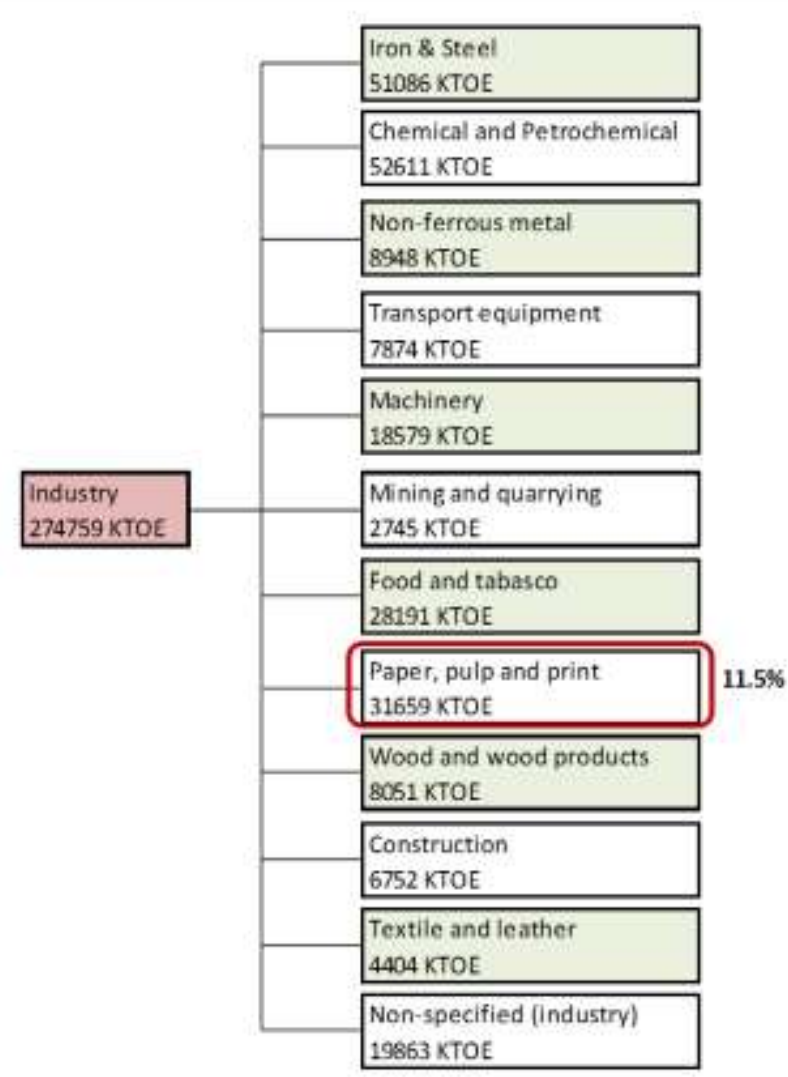

Gambar 2 Konsumsi energi final di sektor industri Uni Eropa pada tahun 2014 [6]

Industri pulp dan kertas Eropa, pengguna energi industri terbesar ke-4 (empat) di UE, memiliki potensi untuk berkontribusi pada tujuan utama yaitu mengatasi perubahan iklim, pengurangan $20 \%, 40 \%$, dan $80 \%$ dalam Emisi GRK dibandingkan dengan tahun 1990 masing-masing pada tahun 2020, 2030 dan 2050. Roadmap UE 2011 menetapkan pengurangan emisi sebesar 43\% tahun 2023 dibandingkan tahun 2005 [6]. Instrumen kebijakan utama untuk mendorong pencapaian tujuan ini adalah Sistem Perdagangan Emisi UE (ETS). Kebijakan Iklim UE juga mendukung inovasi rendah karbon di industri. Setelah tahun 2020, insentif ETS akan disisihkan untuk membuat dana inovasi atau mendukung demonstrasi skala besar dari teknologi rendah karbon yang sangat inovatif.

Mengenai efisiensi energi, satu dari lima strategi Energi Uni Eropa, UE telah menetapkan target penghematan energi $20 \%$ pada tahun 2020 . Arahan efisiensi energi yang direvisi mencakup target baru untuk tahun 2030 sebesar $32,5 \%$.

Pabrik pulp, kertas dan percetakan adalah pengguna energi industri terbesar keempat di UE setelah sektor kimia dan petrokimia, besi dan baja dan mineral non-logam (Gambar 2). Pada tahun 2014, sektor ini mengonsumsi 31.659 kTOE (setara dengan 1.325 PJ), yang merupakan $11,5 \%$ dari konsumsi energi industri final di UE. 


\subsection{Proses Pembuatan Pulp dan Kertas}

Pembuatan pulp diklasifikasikan dalam 3 jenis proses yaitu proses mekanis, semi-kimia dan kimia. Produk yang dihasilkan mempunyai karakteristik serat yang berbeda. Pemilihan jenis proses tersebut tergantung kepada spesies kayu yang tersedia dan penggunaan akhir dari pulp yang diproduksi. Proses kimia mendominasi hampir diseluruh dunia, karena dari pulp ini dapat dibuat berbagai jenis kertas diantaranya adalah kertas budaya. Sebagian besar jenis proses kimia didominasi oleh proses kraft. Proses pembuatan pulp kimia, dapat melarutkan lignin lebih banyak dibandingkan dengan proses yang lain, sehingga dapat menghasilkan kualitas yang lebih baik dan penggunaannya lebih luas.

Selama proses pembuatan pulp, serpih kayu dipisahkan menjadi serat selulosa individu untuk menghilangkan lignin dari kayu. Pembuatan pulp secara kimia (yaitu, kraft, soda, dan sulfit) melibatkan "pemasakan" bahan baku (serpih kayu) menggunakan larutan kimia berair, suhu tinggi dan tekanan untuk mengisolasi serat pulp.

Proses pembuatan pulp kraft menggunakan larutan pemasak alkali yang terdiri dari Sodium Hidroksida $(\mathrm{NaOH})$ dan Sodium Sulfida $\left(\mathrm{Na}_{2} \mathrm{~S}\right)$ untuk melarutkan lignin kayu, sementara proses soda hanya menggunakan $\mathrm{NaOH}$. Larutan pemasak (white liquor) dicampur dengan serpih kayu dalam suatu reaktor (digester) [7]. Setelah serpih kayu masak, isi digester dikeluarkan dengan tekanan ke dalam tangki penampung. Kayu yang melunak, diuraikan menjadi serat pulp. Pulp dan sisa larutan pemasak (lindi hitam) kemudian dipisahkan dalam serangkaian pencucian pulp coklat.

Proses selanjutnya adalah bleaching (pemutihan), merupakan proses untuk meningkatkan tingkat kecerahan kertas untuk keperluan menulis, printing atau kertas dekoratif. Proses ini memisahkan lignin yang melekat pada serat kayu. Pemutihan pulp dari proses kimia dilakukan dengan menggunakan oxidizing agent dan larutan alkali. Proses Kraft menghasilkan kertas dengan kualitas warna yang lebih gelap sehingga memerlukan proses pemutihan. Pulp yang dibuat dari proses mekanik diputihkan dengan menggunakan hydrogen peroksida atau sodium hydrosulfite untuk mengurangi tingkat absorpsi lignin.

Setelah proses pembuatan pulp dan pemutihan, pulp diolah menjadi stok yang digunakan untuk pembuatan kertas. Pada pabrik non-integrasi, pulp yang akan djual dikeringkan, dikemas dan kemudian dikirim ke pabrik kertas. Pada pabrik terintegrasi, pabrik kertas langsung menggunakan pulp yang diproduksi pabrik pulp.

Tahap berikutnya yaitu proses pembuatan kertas, Sebelum masuk ke areal paper machine pulp diolah dulu pada bagian stock preparation. bagian ini berfungsi untuk meramu bahan baku seperti: menambahkan pewarna untuk kertas (dye), menambahkan zat retensi, menambahkan filler (untuk mengisi pori - pori diantara serat kayu), dan lain-lain. Bahan yang keluar dari bagian ini disebut stock (campuran pulp, bahan kimia dan air).

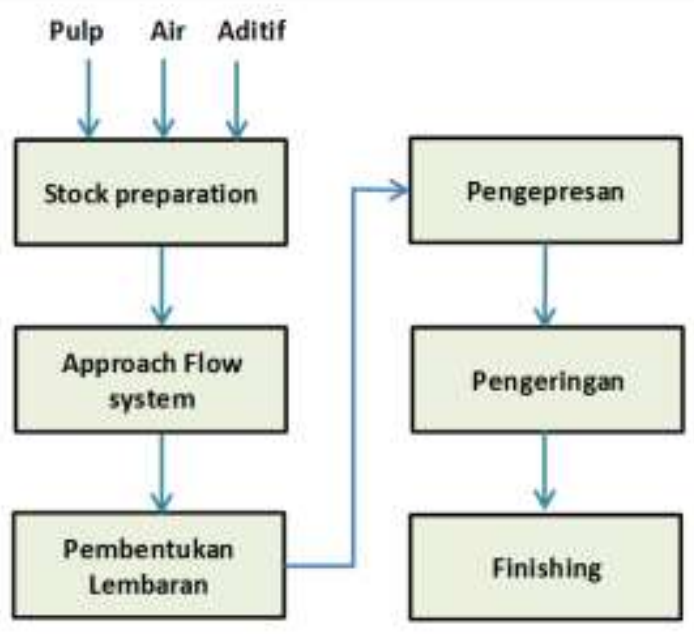

\section{Gambar 3 Diagram proses pembuatan kertas}

Dari stock preparation sebelum masuk ke headbox dibersihkan dulu dengan alat yang disebut cleaner. Dari cleaner stock masuk ke headbox, headbox berfungsi untuk membentuk lembaran kertas (membentuk formasi) diatas fourdinier table. Fourdinier berfungsi untuk membuang air yang berada dalam stock (dewatering). Hasil yang keluar disebut dengan web (kertas basah), kadar padatnya sekitar $20 \%$.

Press part berfungsi untuk membuang air dari web sehingga kadar padatnya mencapai 50\%. Hasilnya masuk ke bagaian pengering (dryer). Cara kerja press part ini adalah kertas masuk diantara dua roll yang berputar. Satu roll bagian atas diberi tekanan sehingga air keluar dari web. Bagian ini dapat menghemat energi, karena kerja dryer tidak terlalu berat (air sudah dibuang 30\%). Dryer berfungsi untuk mengeringkan web sehingga kadar airnya mencapai $6 \%$.

Selanjutnya memasuki tahap calendar stack yang terdiri dari beberapa pasangan silinder dengan jarak tertentu untuk mengontrol ketebalan dan kehalusan hasil akhir kertas. Kemudian memasuki tahap akhir yaitu Pope Reel. Bagian ini merupakan tahap akhir dari proses pembuatan kertas yaitu pemotongan kertas dari gulungannya. Pada bagian ini, kertas yang digulung dalam gulungan besar, dibelah pada ketebalan yang diinginkan, dipotong menjadi lembaran, dirapikan kemudian dikemas.

3.3. Penggunaan Energi di Industri Pulp dan Kertas di Indonesia

Pemerintah telah mengusulkan industri pulp dan kertas untuk dimasukkan dalam kelompok bidang industri pengguna gas bumi harga tertentu pada revisi Perpres 40/2016 tentang penetapan harga gas bumi. Hal ini dilakukan karena Industri pulp dan kertas merupakan salah satu industri prioritas yang telah ditetapkan dalam Peraturan Pemerintah 14/2015 tentang Rencana Induk Pengembangan Industri Nasional (RIPIN).

Peningkatan penggunaan teknologi media online tidak menghambat perkembangan industri pulp dan kertas Indonesia. Hal tersebut dikarenakan permintaan masyarakat dunia terhadap kertas masih tinggi, dimana $60-70 \%$ penggunaan kertas berada di pasar Asia [8]. Kebutuhan kertas dunia saat ini mencapai 394 juta ton dan diperkirakan akan meningkat menjadi 
490 juta ton pada 2020. Sementara itu konsumsi kertas/kapita di dalam negeri masih sangat jauh dari rata-rata konsumsi negara lainnya, sehingga masih berpotensi untuk berkembang.

Sumber energi utama dalam pembuatan pulp dan kertas meliputi energi panas dalam bentuk steam dan energi listrik. Dari keseluruhan proses, penggunaan energi panas mencapai $70-80 \%$ dari total energi yang dikonsumsi, dimana sebagian besar energi digunakan di proses pulping dan pengeringan (drying) [7]. Steam dapat dibangkitkan dari black liquor dan tambahan bahan bakar lainnya seperti batubara, minyak, gas dan biomassa.

Pada tahun 2018, kapasitas terpasang industri pulp dan kertas nasional sebesar 27 juta ton/tahun [9]. Ekspor pulp Indonesia tahun 2017 mencapai US\$ 2,2 miliar, sedangkan ekspor kertas US\$ 3,6 miliar. Pasar utama ekspor pulp didominasi negara seperti China, Korea, India, Bangladesh dan Jepang. Dan ekspor kertas terbesar tercatat menuju negara seperti China, Jepang, Amerika Serikat, Malaysia dan Vietnam [10].

Kebutuhan energi industri pulp dan kertas dihitung dengan mengalikan kapasitas produksi industri tersebut dengan intensitas energinya. Tingkat pertumbuhan produksi pulp dan kertas diasumsi sebesar $2,41 \%$ per tahun. Intensitas energi industri pulp, industri pulp terintegrasi kertas, dan industri kertas sebelum dan setelah konservasi energi ditentukan berdasarkan berbagai referensi dari APP Group, APRIL Group, dan lainnya. Teknologi yang dipertimbangkan mencakup teknologi pengeringan, insinerator, proses pembakaran di boiler, kebocoran uap, pemanfaatan gas kondensasi, sistem batch digester, dan lainnya [11]. Untuk mengkuantifikasi besar penurunan konsumsi energi dan emisi $\mathrm{CO}_{2}$, diasumsikan bahwa terjadi pengurangan energi dan emisi berdasarkan jenis teknologi yang implementasikan pada timeframe (periode) tertentu.

Dari data tahun 2018, intensitas energi di industri pulp berdasarkan penggunaan bahan bakar atau total energi input di industri pulp berada pada kisaran 41,9 GJ/ton pulp. Intensitas konsumsi energi rata-rata untuk industri kertas berada pada kisaran 11,6 GJ/ton kertas, sementara untuk industri pulp dan kertas sekitar 30,2 GJ/ton [11][12]. Nilai intensitas konsumsi energi (IKE) ini diperoleh dari total energi dari bahan bakar input yang digunakan, baik untuk membangkitkan listrik atau steam.

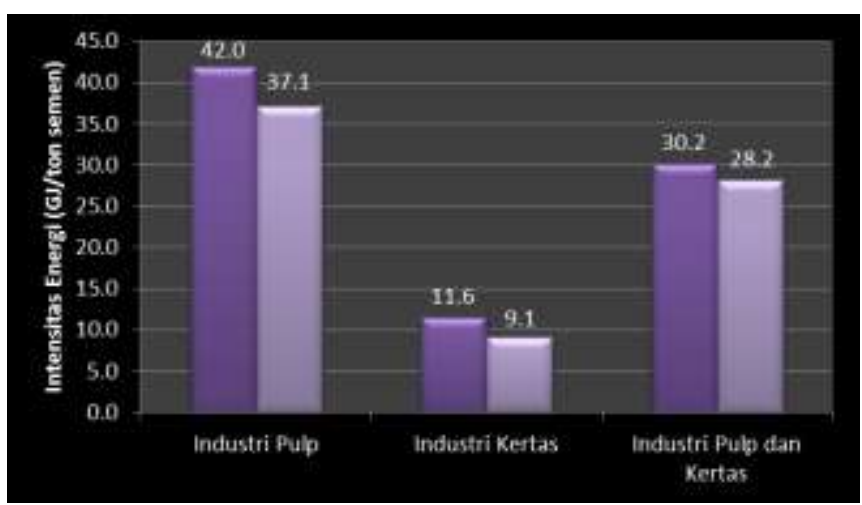

Gambar 4 Intensitas Energi Industri Pulp dan Kertas

Berdasarkan asumsi tersebut maka kebutuhan energi ketiga sub sektor industri ini akan meningkat rata-rata $2,49 \%$ per tahun dari 108,5 juta SBM pada tahun 2018 menjadi 135,4 juta SBM pada tahun 2027. Dengan skenario efisiensi energi, kebutuhan energi industri pulp dan kertas akan menurun sebesar 12,5\% pada tahun 2027. Potensi penghematan energi ketiga sub sektor industri ini mulai tahun 2023 sebanyak 8,4 juta SBM dan menjadi 16,9 juta SBM pada tahun 2027. Besar peluang penghematan energi dan reduksi emisi bervariasi dan bergantung pada berbagai faktor, antara lain tingkat efisiensi proses dan teknologi yang telah diimplementasikan di industri tersebut.

Penurunan kebutuhan energi tersebut juga berdampak terhadap penurunan kebutuhan energi fosil. Penggunaan EBT pada industri pulp dan kertas mencapai $78,6 \%$ sehingga akan menurunkan bauran energi fosil [13]. Potensi penurunan kebutuhan energi fosil di industri pulp dan kertas pada tahun 2027 mencapai 6,3 juta SBM. Hal ini akan berdampak terhadap penurunan impor gas bumi dan BBM. Jenis energi fosil tersebut meliputi batubara, gas bumi, minyak solar, minyak diesel, dan minyak bakar. Penurunan kebutuhan energi fosil tersebut ekuivalen dengan penurunan emisi GRK sebanyak 3,66 juta ton $\mathrm{CO}_{2}$ eq pada tahun 2027.

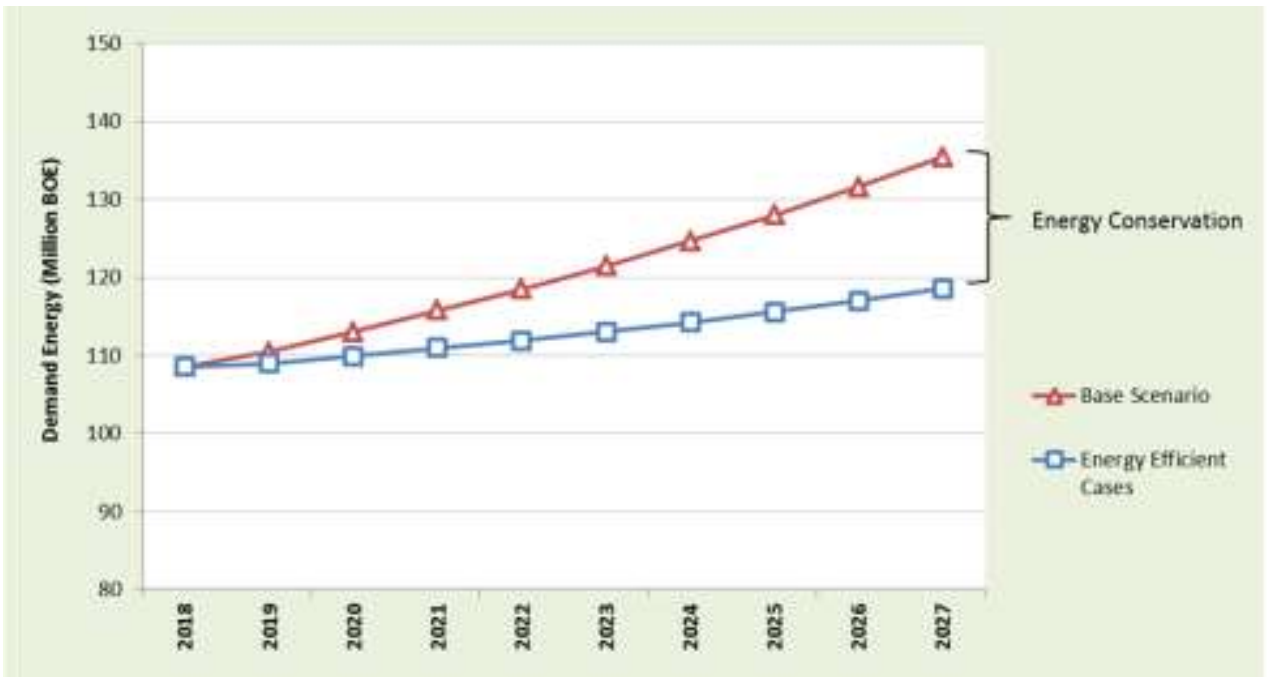

Gambar 5 Proyeksi kebutuhan energi industri pulp dan kertas 


\subsection{Teknologi Pemanfaatan Black Liquor (Lindi Hitam)}

Sebuah pabrik pulp yang memproduksi pulp kraft yang diputihkan menghasilkan 1,7-1,8 ton black liquor (dry content) per ton pulp. Black liquor memiliki potensi sumber energi sebesar 250-500 MW per pabrik [14]. Saat ini, black liquor adalah sumber energi terpenting dari biomassa di negara-negara seperti Swedia dan Finlandia dengan industri pulp dan kertas yang besar. Karena itu sangat menarik untuk mengubah energi primer dalam black liquor (lindi hitam) menjadi sumber energi yang bernilai tinggi.

Di seluruh dunia, industri pulp dan kertas saat ini memproses sekitar 170 juta ton black liquor per tahun, dengan kandungan energi total sekitar 2EJ, menjadikan black liquor sebagai sumber biomassa yang sangat signifikan [14]. Dibandingkan dengan sumber biomassa potensial lainnya untuk produksi bahan kimia, black liquor memiliki keuntungan besar karena sudah diproses sebagian dan ada dalam bentuk cair yang dapat dipompa. Menggunakan black liquor sebagai bahan baku untuk produksi biofuel cair atau gas di proses biorefinery akan memiliki keuntungan sebagai berikut:

- Logistik biomassa sangat sederhana karena bahan baku untuk produksi bahan bakar berada dalam pabrik pulp dan kertas itu sendiri.

- Meningkatkan efisiensi produksi bahan bakar, karena dapat mensibtitusi batubara atau gas bumi sebgai bahan bakar boiler.

- Karena pemrosesan kayu menjadi pulp, syngas yang dihasilkan memiliki kandungan metana yang rendah, yang mengoptimalkan hasil bahan bakar.

- Biaya modal gasifikasi dibagi antara proses recovery bahan kimia anorganik, produksi steam/uap, dan produksi syngas.

Bagian yang sangat penting dari pabrik pulp adalah siklus pemulihan. Dalam siklus ini, energi diperoleh kembali dari bahan organik terlarut dan bahan kimia diregenerasi. Tanpa siklus pemulihan, prosesnya tidak mungkin ekonomis dan ramah lingkungan. Bahan baku untuk siklus pemulihan adalah cairan pemasakan yang telah dipindahkan selama mencuci pulp. Cairan ini mengandung sekitar $78 \%$ dari bahan organik dan $22 \%$ bahan kimia anorganik yang digunakan untuk delignifikasi. Kandungan padatan dari black liquor (lindi hitam) relatif rendah ketika ditarik dari digester, dan untuk menghasilkan bahan yang mudah terbakar, lindi hitam diuapkan sampai kering di plant evaporator multistage.

Setelah penguapan, black liquor dibakar dalam boiler recovery, sering disebut sebagai boiler Tomlinson. Dengan menggunakan proses pembakaran bertahap, kondisi dalam tungku dapat dikurangi di bagian bawah dan pengoksidasi di bagian atas. Dengan cara ini, natrium dan sulfur dapat diperoleh kembali sebagai natrium sulfida cair dan natrium karbonat yang diambil dari bagian bawah boiler. Sementara itu, bahan organik sepenuhnya teroksidasi di bagian atas tungku untuk menyediakan panas untuk menghasilkan uap tekanan tinggi.
Larutan yang diambil dari bawah boiler dikenal sebagai green liquor. Sebelum dapat digunakan kembali dalam proses pemasakan, ion karbonat dalam cairan perlu diganti dengan ion hidroksida. Ini dilakukan melalui proses yang disebut kaustik di mana green liquor bereaksi dengan kapur untuk menghasilkan kalsium karbonat dan natrium hidroksida. Hasilnya disebut white liquor, yang merupakan cairan memasak yang diperlukan untuk memulai proses delignifikasi lagi.

Saat keluar dari digester, black liquor mengandung $15-17 \%$ padatan, terdiri dari organik terlarut dari kayu dan bahan kimia pembuatan pulp. Pabrik pulp menggunakan beberapa ratus ton bahan kimia anorganik per hari. Untuk alasan lingkungan dan ekonomi, diperlukan recovery dan mendaur ulang bahan kimia ini. Black liquor memiliki kandungan organik tinggi dari lignin dan karbohidrat terlarut. Dalam pabrik pulp modern, black liquor biasanya terkonsentrasi hingga $70-80 \%$ padatan kering.

Komposisi black liquor ditunjukkan pada Tabel 1. Kandungan anorganiknya tinggi sekitar $45 \%$ dari black liquor yang keluar dari boiler recovery. Nilai pemanasan per ton padatan lindi hitam relatif rendah, terlepas dari fakta bahwa lindi hitam kaya akan lignin, yang memiliki nilai kalor lebih tinggi daripada komponen utama kayu lainnya.

Tabel 1 Analisis unsur khas dan nilai kalor black liquor (lindi hitam) [14]

\begin{tabular}{|c|c|c|}
\hline Komponen & \multicolumn{2}{|c|}{$\%$ Massa } \\
\hline $\mathrm{C}$ & \multicolumn{2}{|c|}{35.7} \\
\hline $\mathrm{H}$ & \multicolumn{2}{|c|}{3.7} \\
\hline s & \multicolumn{2}{|c|}{4.4} \\
\hline $\mathrm{O}$ & \multicolumn{2}{|c|}{35.8} \\
\hline $\mathrm{Na}$ & \multicolumn{2}{|c|}{19} \\
\hline $\mathrm{K}$ & \multicolumn{2}{|c|}{1.1} \\
\hline $\mathrm{Cl}$ & \multicolumn{2}{|c|}{0.3} \\
\hline $\mathrm{N}$ & \multicolumn{2}{|c|}{$<0.1$} \\
\hline Total $(\%)$ & \multicolumn{2}{|c|}{100} \\
\hline \multicolumn{3}{|c|}{ Karakteristik Pembakaran } \\
\hline Black Liquor, Dry Solids & $\%$ Massa & $80 \%$ \\
\hline $\mathrm{HHV} \mathrm{MJ} / \mathrm{kg}$ & DS & 14.5 \\
\hline $\mathrm{NHV} \mathrm{MJ} / \mathrm{kg}$, & DS & 12.29 \\
\hline
\end{tabular}

Sebuah pabrik yang memproduksi pulp kraft bleached menghasilkan 1,7-1,8 ton black liquor per ton pulp. Black liquor memiliki potensi menghasilkan energi sebesar 250-500 MW per pabrik. Karena pabrik pulp kraft memiliki surplus energi, mereka dapat menjadi pemasok utama bahan bakar terbarukan dalam sistem energi masa depan. Saat ini, black liquor merupakan sumber energi terpenting dari biomassa.

\section{Simpulan}

Konsumsi energi industri pulp dan kertas pada tahun 2018 sebesar 108,5 juta SBM dan tahun 2027 sebesar 135,4 juta SBM. Hasil dari proyeksi efisiensi energi, pada tahun 2027 didapatkan penghematan 
energi sebesar 16,9 juta SBM atau $12,5 \%$ dan penurunan emisi GRK pada tahun 2027 sebesar 3,66 juta ton $\mathrm{CO}_{2}$ eq. Upaya penghematan energi di industri pulp dan kertas dapat dilakukan dengan konservasi energi pada setiap unit proses yaitu sistem pemasakan, pemutihan pulp, chemical recovery, stock preparation, paper machine. Implementasi teknologi efisien pada pembuatan pulp dan kertas pada dasarnya juga melakukan penghematan energi yang sekaligus dapat meningkatkan efisiensi produksi dan profit bagi perusahaan.

Dalam jangka panjang, Industri pulp dan kertas dapat berkontribusi sebagai pemasok energi secara berkelanjutan, diantaranya dengan memasukkan kelebihan listrik ke dalam jaringan PLN. Untuk saat ini industri ini masih terbatas untuk menyuplai listrik ke jaringan, dikarenakan industri masih berfokus pada chemical recovery (white liquor) yang digunakan pada proses pengolahan pulpnya. Kedepan konsep pabrik pulp sebagai biorefineries dapat diterapkan dimana menghasilkan komoditas energi rendah karbon, termasuk biofuel untuk transportasi, dan black liquor.

Hambatan terbesar untuk implementasi langkahlangkah efisiensi energi adalah risiko teknis dan biaya gangguan produksi. Peran instrumen kebijakan disini sangat diperlukan dalam implementasi efisiensi energi, sehingga dapat mendukung investasi efisiensi energi di industri pulp dan kertas.

\section{Ucapan Terima Kasih}

Ucapan terima kasih disampaikan kepada pihak Insentif Riset Sistem Inovasi Nasional (INSINAS) Kementerian Riset, Teknologi, dan Pendidikan Tinggi (Ristekdikti) yang telah memberikan dana penelitian dan kepercayaan untuk melakukan penelitian ini.

\section{Daftar Pustaka}

[1] BPS, PDB Triwulan Atas Dasar Harga Berlaku Menurut Lapangan Usaha (Miliar Rupiah) 20142018, Badan Pusat Statistik, Jakarta, 2018.

[2] KESDM, Handbook of Energy and Economic Statistics of Indonesia 2017, Kementerian Energi dan Sumber Daya Mineral, Jakarta, 2017.

[3] APP, Sustainability Report 2017, Asia Pulp and Paper Indonesia, Jakarta, 2017.

[4] IEA, Energy Technology Perspectives 2017: Informing Energy Sector Transformations, International Energy Agency, Paris, 2017.

[5] IPCC, 2006 IPCC Guidelines for National Greenhouse Gas Inventories, Intergovernmental Panel on Climate Change, Genewa, 2006.

[6] European Commission, Energy Efficiency and GHG Emissions: Prospective Scenario for The Pulp and Paper Industry, European CommissionJoint Research Centre, The Netherlands, 2018.

[7] Kemenperin, Pedoman Pemetaan Teknologi untuk Industri Pulp \& Paper, Kementerian Perindustrian, Jakarta, 2011.
[8] Kemenperin, RI Produsen Kertas Nomor 6 Terbesar Dunia, 2017, [https://kemenperin.go.id/] (Diakses tanggal: 12 Juni 2019)

[9] BISNIS, Industri pulp dan kertas Indonesia Masuk 10 Besar Dunia, 2019. [ekonomi.bisnis.com] (Diakses tanggal: 11 Maret 2019).

[10] KATADATA, Kapasitas Naik, Ekspor Pulp \& Kertas Ditargetkan Tembus Rp 128 Triliun, 2019. [https://katadata.co.id/berita/2019/06/14/kapasitas -naik-ekspor-pulp-kertas-ditargetkan-tembus-rp129-triliun] (Diakses tanggal: 03 Juli 2019).

[11] Kemenperin \& PT EMI, Implementation of Energy Conservation and $\mathrm{CO}_{2}$ Emission Reduction In Industrial Sector, Kementerian Perindustrian dan PT Energy Management Indonesia, Jakarta, 2011.

[12] BPPT, Outlook Energi Indonesia 2017, Badan Pengkajian dan Penerapan Teknologi, Jakarta, 2017.

[13] APRIL, Sustainability Report 2017, APRIL Group, Jakarta, 2018.

[14] IEA, Black Liquor Gasification, Summary and Conclusions from IEA Bioenergy ExCo54 Workshop, International Energy Agency, Paris, 2007. 